\title{
Analisis Hematologi Kelinci setelah Implantasi Ultra High Molecular Weight Poliethylene (UHMWPE) pada Sendi Lutut
}

\section{The Hamatology Analysis of Rabbit after Implantation by Ultra High Molecular Weight Poliethylene (UHMWPE) on Knee Joint}

\author{
Alyda Aliyah Rahmah ${ }^{1}$, Silvana Tana ${ }^{2}$, Siti Muflichatun Mardiati ${ }^{2}$ \\ ${ }^{1)}$ Program Studi Biologi, Departemen Biologi, Fakultas Sains dan Matematika, Universitas Diponegoro \\ ${ }^{2)}$ Departemen Biologi, Fakultas Sains dan Matematika, Universitas Diponegoro \\ Jl. Prof. Soedarto, SH, Tembalang, Semarang \\ *Email : alydaliyastra@gmail.com
}

Diterima 11 Desember 2016 / Disetujui 21 Agustus 2017

\begin{abstract}
ABSTRAK
Penelitian ini bertujuan untuk menganalisis respon fisiologi tubuh kelinci terhadap implantasi Ultra High Molecular Weight Poliethylene (UHMWPE) dilihat dari aspek jumlah eritrosit, jumlah leukosit dan kadar hemoglobin sebagai salah satu data pendukung untuk dasar penelitian lebih lanjut dalam rangka pembuatan sendi buatan yang sesuai dengan anatomi tubuh orang Indonesia. Penelitian ini menggunakan Rancangan Acak Kelompok menggunakan 6 ekor kelinci jenis Lop umur 2,5 bulan yang dibagi dalam dua (2) perlakuan yaitu membandingkan kelinci yang tidak diberikan implantasi UHMWPE (kontrol) (P0) dengan kelinci yang diberikan perlakuan implantasi UHMWPE (P1). Parameter utama adalah jumlah eritrosit, jumlah leukosit dan kadar hemoglobin, serta parameter pendukung adalah konsumsi pakan dan bobot tubuh kemudian dianalisis dengan Uji T Sampel Independen dengan bantuan perangkat lunak SPSS pada taraf kepercayaan 95\%. Hasil penelitian menunjukkan bahwa jumlah eritrosit, jumlah leukosit dan kadar hemoglobin berbeda tidak nyata $(p>0,05)$ antara kontrol dengan perlakuan. Penggunaan implantasi UHMWPE selama 2,5 bulan tidak menyebabkan perubahan pada jumlah eritrosit, jumlah leukosit dan kadar hemoglobin dalam tubuh hewan model. Hal ini dapat disimpulkan bahwa material UHMWPE merupakan material implan yang dapat digunakan pada tubuh manusia.
\end{abstract}

Kata Kunci : Ultra High Molecular Weight Poliethylene (UHMWPE), Kelinci, hematologi

\begin{abstract}
This research aims to analyze the physiological response of rabbits body after implantation Ultra High Molecular Weight Poliethylene (UHMWPE) seen from the aspect of erythrocyte number, leukocyte number and hemoglobin level as one of supporting data for further basic research in order to manufacture artificial joints in accordance with the anatomy of Indonesian human body. This study used a Random Draft Group using the 6 tail rabbit 2.5 months of age type of Lop which is divided in two (2) treatment i.e. compare the rabbits not given implantation UHMWPE (control) (P0) and rabbits given treatment implantation UHMWPE (P1). The main parameters are the number of erythrocytes, the number of leukocytes and levels of hemoglobin, as well as the supporting parameter is the body weights and feed consumption is then analyzed by T-test for independent Samples with the help of SPSS software at 95\% confidence level. The results showed that the number of erythrocyte, leukocyte count and hemoglobin levels did not different significantly ( $p>0.05$ ) between control and treatment. Use UHMWPE for 2.5 months of implantation does not cause a change in the number of erythrocytes, haemoglobin levels and number of leukoksit in the body of an animal model. It can be concluded that UHMWPE implant material is a material that can be used on the human body.
\end{abstract}

Keywords : Ultra High Molecular Weight Poliethylene (UHMWPE), rabbit, hematology 


\section{PENDAHULUAN}

Tulang dan sendi merupakan organ yang tersusun dalam suatu rangkaian yang membentuk sistem kerangka. Sendi atau artikulasi merupakan pertemuan antara dua atau beberapa tulang dari sistem kerangka, sehingga tulang-tulang tersebut dapat digerakkan sesuai dengan jenis persendiannya. Sistem kerangka tersusun dari tulang-tulang yang bersatu membentuk suatu fungsi yaitu alat gerak. Tulang merupakan bagian tubuh yang memiliki banyak fungsi diantaranya pembentuk rangka tubuh, tempat penyimpanan kalsium dan pada tulang panjang terdapat sumsum tulang yang memiliki sifat pluripoten yang dapat menghasilkan sel-sel bagi tubuh. Hal ini menjadikan tulang dan sendi sebagai bagian penting dalam tubuh, sehingga kerusakan tulang dan sendi dapat mengganggu keseimbangan dan berjalannya proses dalam tubuh (Pearce, 2006).

Peranan tulang dan sendi sangat tinggi dalam menopang tubuh manusia. Kenyataannya setiap tahun jutaan orang di dunia menderita berbagai insiden yang dapat menyebabkan kerusakan pada tulang dan sendi berupa patahan atau retakan (fraktur). Fraktur merupakan suatu keadaan terputusnya kontinuitas pada tulang akibat trauma. Penyebab banyaknya adalah insiden kecelakaan, tetapi ada beberapa faktor lain seperti proses degenerasi tulang rawan (osteoarthrosis/OA), Rheumatoidarthritis (RA) dan pengeroposan tulang (osteoporosis) (Darwis, 2008). Osteoarthrosis merupakan kasus yang paling sering terjadi, yaitu keausan pada femoral bone dan tibial bone akibat kontak sliding yang biasanya terjadi pada orang-orang usia lanjut. Banyak riset yang dilakukan dengan menggunakan biomaterial sebagai pengganti sendi lutut antara lain titanium alloy, cobalt alloy, stainless steel untuk komponen femoral, sedangkan ultra high molecular weight polyethylene (UHMWPE) sebagai komponen bantalan tibial (Darmanto, 2011).

Peningkatan berbagai kasus penyakit tulang dan sendi pada manusia, semakin meningkatkan kebutuhan graft tulang atau biomaterial yang sesuai. Penyembuhan secara spontan pada beberapa kerusakan tulang tersebut tidak mampu mengembalikan stabilitas fisiologis yang diperlukan. Berbagai kasus yang terjadi bahan pengganti tulang dan sendi sering diperlukan untuk merekonstruksi struktur anatomi dan memulihkan stabilitas tulang (Huber et al., 2009). Biomaterial sintetis dapat menjadi pilihan lain untuk mengatasi bagian tulang dan sendi yang patah atau retak. Biomaterial sintesis merupakan suatu material inert (tidak bereaksi) yang digunakan untuk implantasi pada sistem makhluk hidup, untuk menggantikan fungsi dari organ makhluk hidup tersebut. Biomaterial pengganti tulang yang ideal harus memiliki sifat antara lain bioaktif yaitu kemampuan material bereaksi dengan jaringan dan menghasilkan senyawa kimia yang sangat baik untuk aktifitas biologi dalam tubuh seperti vitamin dan mineral; osteokonduktif merupakan kemampuan material untuk merangsang sel-sel osteoblas untuk melakukan mineralisasi tulang. Biokompatibel merupakan kemampuan material untuk menyesuaikan dengan kecocokan tubuh penerima, serta stabil secara biomekanis yaitu sesuai dengan kemampuan fisik manusia ketika melakukan aktivitas kerja, dan bebas dari agen penyakit (Samsiah, 2009).

Material UHMWPE merupakan salah satu jenis polimer dengan kerapatan dan berat molekul tinggi yang dibuat dari polimerisasi etilen dengan katalis metallocene (Jarijah, 2008). Material UHMWPE ini dapat digunakan sebagai implan pada sendi lutut tiruan pada manusia, akan tetapi penelitian-penelitian yang terkait mengenai pengaruh material tersebut terhadap tubuh masih sangat terbatas. Hal ini memberikan kesempatan untuk dilakukan penelitian terhadap hewan uji dengan pemasangan implan material tersebut. Penelitian ini dilakukan pada hewan uji, salah satu jenis hewan yang dapat digunakan adalah kelinci. Hal ini dikarenakan rangka tulang kelinci khususnya pada bagian patella memiliki kemiripan dengan manusia, selain itu kelinci juga masih dalam satu kelompok yang sama dengan manusia, yaitu mammalia.

Salah satu cara untuk mengetahui kondisi kesehatan hewan model dapat dilakukan dengan pengamatan terhadap status hematologi. Hematologi merupakan cabang ilmu biologi yang 
mempelajari mengenai darah. Status hematologi dapat menjadi sumber informasi untuk mengetahui kondisi kesehatan tubuh suatu individu karena keterkaitan darah dengan jaringan-jaringan tubuh lainnya serta bentuk imunitas tubuh yang dilakukan oleh darah sebagai respon masuknya patogen atau material asing pada jaringan. Beberapa bentuk pengukuran hematologi meliputi kadar hemoglobin, jumlah eritrosit dan jumlah leukosit (Pearce, 2006).

Berdasarkan penjelasan di atas maka dilakukan penelitian untuk mengetahui pengaruh pemasangan implan UHMWPE pada patella terhadap darah, jaringan di sekitar, maupun fisiologis secara umum. Pada penelitian ini hanya fokus pada pengaruh implan UHMWPE terhadap status hematologi. Pengamatan hematologi yang dilakukan meliputi pengamatan nilai hemoglobin, jumlah eritrosit, dan leukosit. Nilai hemoglobin dan jumlah eritrosit dapat menjadi acuan terhadap ketersediaan oksigen, zat besi, dan nutrisi penting lainnya bagi individu. Jumlah leukosit dapat menjadi acuan untuk mengetahui kondisi responsif tubuh terhadap adanya material asing yaitu implan pada hewan model tersebut.

\section{METODE PENELITIAN}

\section{Tempat dan Waktu Penelitian}

Penelitian ini dilakukan di Laboratorium Biologi Struktur dan Fungsi Hewan, Jurusan Biologi, Fakultas Sains dan Matematika, Universitas Diponegoro Semarang selama 13 minggu pada bulan September - Desember 2012.

\section{Alat dan Bahan}

Alat-alat yang digunakan dalam penelitian ini yaitu kandang pemeliharaan dan perlengkapannya (tempat makan dan minum), set alat bedah, set alat kebersihan, timbangan untuk menimbang pakan dan berat badan, pengukur suhu dan kelembapan, gelas ukur untuk mengukur volume air minum, improved neubauer, gelas penutup, mikroskop, venojek EDTA, haemometer sahli.
Bahan-bahan yang digunakan dalam penelitian ini terbagi menjadi dua yaitu bahan keperluan saat pembedahan dan bahan untuk menghitung jumlah darah. Bahan keperluan saat pembedahaan yaitu antibiotik, anastesi, iodine povidon, alkohol, kapas, dan kasa penutup luka. Bahan yang digunakan untuk menghitung jumlah darah yaitu aquades, larutan hayem dan turk.

\section{Pemeliharaan Hewan Model}

Pemeliharaan hewan model dilakukan pada kandang persegi dengan ukuran $1,5 \times 1,5$ meter. Kandang tersebut dibagi menjadi enam kotak kandang kecil yang berukuran $0,5 \times 0,5$ meter untuk satu individu. Enam (6) ekor kelinci selanjutnya dibagi dalam dua kelompok yaitu kelompok kontrol dan kelompok perlakuan masing-masing terdiri atas tiga ekor. Kelompok kontrol disebut P0 sedangkan kelompok perlakuan disebut P1. Kelinci ditempatkan pada kandang sesuai dengan kelompok perlakuan. Kandang terbuat dari kayu sebagai kerangka kandang dengan penutup kandang terbuat dari anyaman kawat. Hewan model dipelihara selama 2 minggu sebelum dilakukan proses pemasangan implan. Tempat kotoran diletakkan dibagian bawah masing-masing kandang individu.

\section{Pemasangan Implan}

Material implan yang digunakan adalah polietilen berjenis UHMWPE berbentuk bola berwarna putih dengan ukuran diameter $5 \mathrm{~mm}$. Implan dipasangkan dengan cara pembedahan ortopedis. Pembedahan dan pemasangan implan pada semua hewan model dilakukan oleh tenaga ahli RSO Prof. Dr. Soeharso Surakarta. Implan UHMWPE dipasang pada patella kanan. Hewan model kemudian dipelihara selama 10 minggu.

\section{Pengambilan Data}

Pengambilan sampel darah dilakukan melalui vena jugularis. Darah kemudian ditampung ke dalam tabung venojek dengan volume maksimal $3 \mathrm{~mL}$.Tiap individu kelinci 
diambil sampel darah sebanyak dua tabung venojek.

\section{Penentuan Kadar Hemoglobin}

Pengukuran pada kadar hemoglobin dilakukan dengan metode Sahli.

\section{Penentuan Jumlah Eritrosit}

Penentuan jumlah eritrosit dilakukan dengan menggunakan bilik hitung Improved neubauer pada mikroskop. Butir darah merah dihitung dengan menggunakan teknik lima bujur kecil pada kamar hitung eritrosit.

\section{Penentuan Jumlah Leukosit}

Penentuan jumlah eritrosit dilakukan dengan menggunakan bilik hitung Improved neubauer pada mikroskop. Butir darah putih dihitung dengan menggunakan teknik empat bujur sangkar besar pada kamar hitung leukosit.

\section{Rancangan Penelitian dan Analisis Data}

Rancangan penelitian ini adalah Rancangan Acak Lengkap terdiri atas 2 perlakuan 3 ulangan. Data yang diperoleh dari kelompok perlakuan Polietilen (P1) dibandingkan dengan kelompok kontrol (P0) dengan menggunakan Uji T sampel independen pada taraf kepercayaan 95\%. Pengolahan data menggunakan perangkat lunak SPSS (Santoso, 2008).

\section{HASIL DAN PEMBAHASAN}

Hasil analisis uji $\mathrm{T}$ dengan sampel independen pada taraf kepercayaan 95\%, data hasil penelitian penggunaan implan yang berbahan polietilen berjenis UHMWPE pada sendi lutut kelinci menunjukkan berbeda tidak nyata atau tidak ada pengaruh implan terhadap status hematologi yaitu berupa jumlah eritrosit, jumlah leukosit, dan kadar hemoglobin. Data hasil analisisnya disajikan pada Tabel 1 , dengan tambahan data pendukung berupa data konsumsi pakan dan bobot tubuh kelinci selama 2,5 bulan.
Tabel 1. Hasil analisis rerata jumlah eritrosit, jumlah leukosit, kadar hemoglobin, konsumsi pakan dan bobot tubuh kelinci setelah implantasi UHMWPE selama 2,5 bulan

\begin{tabular}{lcc}
\hline \multicolumn{1}{c}{ Parameter } & \multicolumn{2}{c}{ Perlakuan } \\
\cline { 2 - 3 } & P0 & P1 \\
\hline $\begin{array}{l}\text { Jumlah Eritrosit } \\
\left(\mathrm{sel} / \mathrm{mm}^{3}\right)\end{array}$ & $\left(5,22 \times 10^{6}\right)^{\mathrm{a}}$ & $\left(5,6 \times 10^{6}\right)^{\mathrm{a}}$ \\
$\begin{array}{l}\text { Jumlah Leukosit } \\
\left(\mathrm{sel} / \mathrm{mm}^{3}\right)\end{array}$ & $\left(3,75 \times 10^{3}\right)^{\mathrm{a}}$ & $\left(4,01 \times 10^{3}\right)^{\mathrm{a}}$ \\
$\begin{array}{l}\text { Kadar Hemoglobin } \\
(\mathrm{g} / \mathrm{dL})\end{array}$ & $10,5^{\mathrm{a}}$ & $11,33^{\mathrm{a}}$ \\
$\begin{array}{l}\text { Bobot Tubuh } \\
\text { gram) }\end{array}$ & $1.915^{\mathrm{a}}$ & $1.813^{\mathrm{a}}$ \\
$\begin{array}{l}\text { Konsumsi Pakan } \\
\text { Harian (g) }\end{array}$ & $90^{\mathrm{a}}$ & $86^{\mathrm{a}}$ \\
\hline
\end{tabular}

Keterangan : Superskrip yang sama pada baris yang sama menunjukkan berbeda tidak nyata pada taraf kepercayaan 95\%. P0 merupakan hewan uji kontrol tanpa perlakuan, P1 merupakan hewan uji dengan perlakuan implantasi UHMWPE

Darah merupakan salah satu parameter dari status kesehatan hewan, karena darah merupakan komponen yang memiliki fungsi penting dalam pengaturan fisiologis tubuh. Hoffbrand dan Pettit (1996) menjelaskan bahwa fungsi darah secara umum berkaitan dengan transportasi komponen di dalam tubuh seperti nutrisi, oksigen, karbondioksida, metabolisme, hormon, kelenjar endokrin, dan sistem imun tubuh. Darah memiliki peranan yang sangat kompleks untuk terjadinya proses fisiologis yang berjalan dengan baik, sehingga menjadi indikator tubuh yang optimal.

Berdasarkan hasil analisis tersebut, jumlah eritrosit kelinci perlakuan yang menggunakan implan UHMWPE menunjukkan hasil sebesar 5,6 x $10^{6} \mathrm{sel} / \mathrm{mm}^{3}$, sedangkan kelinci yang tidak diberikan perlakuan menunjukkan rerata jumlah eritrosit 5,22 x $10^{6} \mathrm{sel} / \mathrm{mm}^{3}$. Hasil tersebut berbeda tidak nyata, sehingga dapat dikatakan bahwa jumlah eritrosit kelinci perlakuan dan kelinci yang tidak diberi perlakuan dalam jumlah yang normal sesuai dengan data fisiologis menurut Budiono (2008), menyatakan bahwa jumlah sel darah merah pada kelinci normal sekitar 4-7 juta/ $\mathrm{mm}^{3}$. 
Tubuh hewan yang mengalami perubahan fisiologis maka status darah juga akan mengalami perubahan jumlah di dalam tubuh. Perubahan fisiologis ini dapat disebabkan secara internal dan eksternal. Guyton and Hall (2006), menyatakan bahwa jumlah darah yang berada di dalam tubuh dipengaruhi oleh dua faktor yaitu faktor eksogen, meliputi hadirnya agen penyebab infeksi dan perubahan lingkungan yang terjadi. Faktor endogen yang meliputi pertambahan umur, status kesehatan, gizi, stres, dan suhu tubuh. Jumlah eritrosit dipengaruhi juga oleh nutrisi dalam pakan, Darmawan (2002) menyebutkan bahwa bahan penting yang dibutuhkan dalam pembentukan eritrosit antara lain protein (asam amino), vitamin (vitamin B2, B6, B12, folat, tiamin, vitamin C, dan E), dan mineral ( $\mathrm{Fe}, \mathrm{Cu}, \mathrm{Mn}$, dan $\mathrm{Co}$ ). Bila tubuh mengalami defisiensi salah satu bahan-bahan penting tersebut, maka proses pembentukan eritrosit akan terganggu dan dapat menyebabkan terjadinya anemia.

Penggunaan implan pada kelinci perlakuan menunjukkan bahwa implantasi UHMWPE selama perlakuan 2,5 bulan tidak memberikan perubahan yang signifikan. Hal ini karena adanya faktor eksogen berupa implan, dan faktor endogen seperti stres sudah tidak lagi di alami kelinci pasca implantasi 2,5 bulan. Hasil analisis tersebut menunjukkan berbeda tidak nyata, sehingga asupan nutrisi kelinci yang diberikan perlakuan pun sudah terpenuhi.

Hemoglobin merupakan senyawa pembawa oksigen serta sebagai protein berpigmen merah yang terdapat pada eritrosit. Kadar hemoglobin yang rendah mengindikasikan adanya penyakit anemia. Berdasarkan rerata hasil analisis kadar hemoglobin pada kelinci model tidak menunjukkan pengaruh yang signifikan, karena kadar hemoglobin pada kelinci perlakuan sebesar $11,33 \mathrm{~g} / \mathrm{dL}$ sedangkan pada kelinci yang tidak diberi perlakuan memiliki rerata kadar hemoglobin sebesar 10,5 g/dL. Hasil penelitian ini sesuai dengan pernyataan Budiono (2008) bahwa kadar hemoglobin kelinci normal, yaitu 9-15 g/dL. Pembentukan hemoglobin terjadi selama proses eritropoeisis, menurut Haen (1995) jika proses eritropoeisis terganggu maka produksi sel darah merah akan menurun yang mengakibatkan terjadinya kondisi anemia yang ditandai dengan kadar hemoglobin yang rendah/kurang dari normal. Hoffbrand dan Pettit (1996), menjelaskan bahwa pembentukan hemoglobin dalam eritrosit sangat ditentukan oleh asupan nutrisi terutama protein dan mineral zat besi. Zat besi yang ada di dalam tubuh berasal dari tiga sumber yaitu zat besi yang diperoleh dari hasil perusakan sel-sel darah merah (hemolisis), zat besi yang diambil dari penyimpanan dalam tubuh, dan zat besi yang diserap dalam saluran pencernaan. Berdasarkan dari ketiga sumber tersebut zat besi hasil hemolisis merupakan sumber utama. Zat besi pada hewan atau manusia dalam keadaan normal kira-kira $70 \%$ perhari berasal dari hemolisis dan sekitar 5\% yang berasal dari makanan yang di konsumsi serta $25 \%$ yang berasal dari penyimpanan dalam tubuh.

Hemoglobin berkaitan erat dengan eritrosit, karena sintesis hemoglobin terjadi pada awal pembentukan eritrosit. Sesuai dengan rerata hasil analisis eritrosit yang stabil, maka kadar hemoglobin dalam tubuh kelinci pun normal dan ini memberikan bukti bahwa UHMWPE tidak memberikan pengaruh yang buruk terhadap status hematologi dan kondisi kesehatan kelinci. Haen (1995), menjelaskan bahwa setiap fluktuasi kadar hemoglobin dalam darah memiliki pengaruh yang signifikan terhadap kinerja metabolisme dan kondisi kesehatan manusia atau hewan.

Leukosit merupakan unit aktif dari sistem pertahanan tubuh. Fungsi leukosit adalah sebagai pertahanan tubuh untuk melawan benda asing yang masuk ke dalam tubuh (Guyton and Hall, 2006). Berdasarkan rerata hasil analisis pada jumlah leukosit kelinci menunjukkan angka sebesar 4,01 x $10^{3} \mathrm{sel} / \mathrm{mm}^{3}$ untuk kelinci perlakuan, sedangkan untuk kelinci yang tidak diberi perlakuan menunjukkan angka sebesar $3,75 \times 10^{3} \mathrm{sel} / \mathrm{mm}^{3}$. Hasil tersebut berbeda tidak nyata, karena masih dalam rentang jumlah leukosit normal. Sesuai dengan pernyataan Rukayah (2008), jumlah normal leukosit kelinci berkisar antara 3-12 $\mathrm{ribu} / \mathrm{mm}^{3}$.

Respon leukosit muncul pada keadaan patologis, berupa peningkatan salah satu atau beberapa jenis sel leukosit. Granulosit dan monosit 
melindungi tubuh terhadap organisme penyerang terutama dengan cara mencernanya yaitu melalui fagositosis (Jain, 1993). Kondisi yang berubah akibat adanya infeksi akan mengakibatkan perubahan fisiologis, yang akan berpengaruh pada perubahan nilai hematologi. Ma'ruf dkk. (2005), menjelaskan bahwa perubahan akibat adanya inflamasi ditandai dengan perubahan suhu tubuh yang meningkat, karena akibat adanya aktivitas sistem kekebalan tubuh yang bekerja melawan agen penyakit dan jika dilihat dari nilai hematologi maka jumlah leukosit dalam darah akan mengalami peningkatan. Peningkatan sel leukosit dapat menjadi indikator suatu penyakit yang diakibatkan oleh benda asing.

Inflamasi adalah respon fisiologis tubuh terhadap suatu injuri dan gangguan oleh faktor eksternal. Inflamasi terbagi menjadi dua pola dasar. Inflamasi akut adalah radang yang berlangsung relatif singkat, dari beberapa menit sampai beberapa hari, dan ditandai dengan perubahan vaskular, eksudasi cairan dan protein plasma serta akumulasi neutrofil yang meningkat. Inflamasi akut dapat berkembang menjadi suatu inflamasi kronis jika agen penyebab injuri masih tetap ada. Inflamasi kronis adalah respon proliferatif dimana terjadi proliferasi fibroblas, endotelium vaskuler, dan infiltrasi sel mononuklear (limfosit, sel plasma dan makrofag). Respon peradangan meliputi suatu perangkat kompleks yang mempengaruhi perubahan vaskular dan selular (Mitchell and Cotran, 2003).

Berdasarkan hasil analisis pada leukosit menunjukkan tidak ada perubahan jumlah leukosit yang secara signifikan, maka dapat dikatakan bahwa luka akibat pemasangan implan sudah dalam tahap penyembuhan dan implan UHMWPE dianggap tidak lagi menjadi benda asing yang berbahaya di dalam tubuh. Penggunaan antibiotik sebelum dan pasca operasi membantu mencegah terjadinya infeksi, sehingga pemberian antibiotik membantu kerja leukosit dalam melawan antigen masuk ke dalam tubuh yang dapat menyebabkan inflamasi akut. Penanganan luka pasca operasi dilakukan dengan baik yaitu dengan penggantian kasa yang diberi antiseptik berupa iodine povidon secara berkala serta asupan nutrisi yang baik.
Bruun et al. (2004), menyatakan bahwa malnutrisi berhubungan dengan menurunnya fungsi otot, fungsi respirasi, fungsi imun, dan gangguan pada proses penyembuhan luka.

Kondisi yang mempengaruhi fisiologis tubuh lainnya adalah pakan. Asupan gizi dan nutrisi yang terpenuhi tentu akan membantu proses pemulihan fisiologi kelinci pasca operasi. North and Bell (1990), menyatakan nutrisi dalam pakan digunakan tubuh untuk menjaga keberlangsungan proses fisiologis yang secara umum berupa kebutuhan hidup pokok, pertumbuhan, dan deposit lemak.

Rerata hasil analisis pada bobot tubuh kelinci pasca operasi dengan pemeliharaan selama 10 minggu menunjukkan berbeda tidak nyata dengan kelinci yang tidak diberi perlakuan. Data tersebut juga di dukung dengan hasil rerata pakan harian yang menunjukkan tidak adanya perbedaan yang signifikan pasca operasi. Bobot tubuh kelinci perlakuan menunjukkan rerata sebesar 1.813 gram dengan pakan harian sebanyak 86 gram, sedangkan pada kelinci yang tidak diberi perlakuan memiliki rerata bobot tubuh sebesar 1.915 dan dengan pakan harian sebanyak 90 gram.

Pemberian nutrisi yang lengkap memberikan dampak positif terhadap kondisi fisiologi kelinci, dengan demikian proses pembentukan darah dan proses pemulihan luka pasca operasi tidak akan terganggu dan akan cepat pulih. Salah satu faktor kestabilan kondisi kesehatan hewan dapat dilihat dari kebutuhan nutrisi yang terpenuhi. Torosian (2004), menyatakan bahwa nutrisi dibutuhkan selama fase integrasi implan dan penyembuhan luka akibat perlukaan yang ditimbulkan saat operasi. Secara fisiologis pasca operasi terjadi peningkatan metabolik untuk energi dan perbaikan, kebutuhan nutrien digunakan untuk homeostasis, pemulihan, dan rehabilitasi ke kondisi normal. Energi yang diperoleh dari pakan nantinya akan digunakan untuk pembentukan berbagai jaringan atau dideposisi sebagai cadangan lemak.

\section{KESIMPULAN}

Berdasarkan hasil analisis, data hasil penelitian mengenai pemasangan implan berbahan 
polietilen yang berjenis UHMWPE pada sendi lutut kelinci dengan parameter utama kadar hemoglobin, penghitungan jumlah eritrosit dan leukosit, serta dengan parameter pendukung berupa konsumsi pakan dan bobot tubuh menunjukkan tidak adanya pengaruh terhadap status hematologi kelinci model. Hal ini dapat disimpulkan bahwa Polietilen UHMWPE merupakan material implan yang aman dan dapat di terima oleh tubuh.

\section{DAFTAR PUSTAKA}

Budiono. 2008. Gambaran Darah Merah Kelinci yang Divaksin Ekstrak Caplak Rhipicephalus sanguinis. Skripsi. Institut Pertanian Bogor.

Bruun, L.I, Bosaeus, Bergstad, and Nyagaard. 2004. Prevalence of Malnutrition In Surgical Patients : evaluation of nutritional support and documentation. Clinutrition ; 18(3):141-147.

Darmanto. 2011. Effect on Lubricant Protein Concentration of UHMWPE wear by $316 \mathrm{~L}$ Stainless Steel with Nitrogen Ion Implantation for Application of Artificial Knee Joints. Thesis. UGM : Yogyakarta.

Darmawan, N.S. 2002. Pengantar Patologi Klinik Veteriner (Hematologi Klinik) cetakan II. Pelawa Sari : Denpasar.

Darwis, D. 2008. Biomaterial untuk Keperluan Klinis. (terhubung berkala). http://nhc.batan.go.id/. Diakses pada Tanggal 23 September 2013.

Guyton, A.C, and Hall, J.E. 2006. Medical Physiology Edisi 11. Jakarta: Penerbit Buku Kedokteran EGC. Terjemahan dari : Review of medical physiology $11^{\text {th }}$ edition

Haen, P.J. 1995. Principles of Hematology. ( $E d s)$ by Linda Harris and Young. Loyola Marymont University. Wm. C. Brown Publishers : Chicago USA.

Hoffbrand A.V, dan Pettit, J.E. 1996. Kapita Selekta Hematologi. Ed ke-2. Iyan D, penerjemah. Jakarta : Penerbit Buku
Kedokteran, EGC. Terjemahan dari : Essential Hematology.

Huber, F.X, McArthur, N., Heimann, L., Dingeldein, E., Cavey, H., Palazzi, X., Clermont, G., and Boutrand, J.P. 2009. Evaluation of a Novel Nanocrystalline Hydroxyapatite Paste Ostim ${ }^{\circledR}$ in Comparison to Alpha-BSM ${ }^{\circledR}$ - More Bone Ingrowth Inside the Implanted Material with Ostim ${ }^{\circledR}$ Compared to Alpha BSM®. BMC Musculoskelet Disord. 10: 164.

Jain, N.C. 1993. Essentials of Veterinary Hemathology. Lea and Febiger: Philadelphia.

Jarijah, R. 2008. Synthesizing UHMWPE Using Zieglen-Natta Catalyst System of $\mathrm{MgCl} 2$ (Ethoxide Type)/TiCl4/Tri isobutylalumunium. $\mathrm{VCH}$ Verlag $\mathrm{GmbH}$. 274(2) : 148-153.

Ma'ruf, A., Atmoko, T., dan Syahbani, I. 2005. Teknologi penangkaran rusa Sambar (Cervus unicolor) di desa Api-api Kabupaten Penajem Paser Utara Kalimantan Timur. Di dalam: Gelar dan dialog teknologi di Mataram; 29-30 Juni . Peneliti pada Lokakarya Litbang Satwa Primata Samboja; hlm $57-68$.

Mitchell, R.N. and Cotran, R.S. (2003). Acute and chronic inflammation. By in S. L. Robbins and V. Kumar, Robbins Basic Pathology $7^{\text {th }}$ edition (pp.33-59). Elsevier Saunders : Philadelphia.

North and Bell. 1990. Commercial Chicken Production Manual 3rd Edition. The Avi Publishing Company, Inc : Wesport, Connecticut.

Pearce, E. 2006. Anatomi dan Fisiologi untuk Paramedis. Gramedia Pustaka Utama, Jakarta.

Rukayah, S. 2008. Gambaran Sel Darah Putih pada Kelinci yang Divaksin dengan Ekstrak Caplak Rhipicephalus sanguinis. Skripsi. Institut Pertanian Bogor.

Samsiah, R. 2009. Karakterisasi Biokomposit Apatit-Kitosan dengan XRD (X-RAY 
difraction), FTIR (fourier transform infrared), SEM (scanning electron microscopy) dan Uji mekanik. Skripsi. Fakultas Matematika dan Ilmu Pengetahuan Alam, Institut Pertanian Bogor .

Santoso, S. 2008. Panduan lengkap menguasai SPSS 16. Jakarta : PT Elex Media Komputindo, $237-248$.

Torosian, M.H. 2004. Perioperative Nutrition Support For Patients Undergoing Gastointestinal Surgery : Critical Analisis And Recommendation. World Journal Surgery. $23: 565-9$ 